\title{
Riboflavine Concentration of the Biopsied Livers from Children with or without Nutritional Dystrophy
}

Studies on the Nutrition of Children in Hirosaki Area

(47th Report)

By

\author{
Akira Kagaya and Jiro Takahashi \\ (加賀谷 晃) (高橋二郎) \\ From the Department of Pediatrics, School of Medicine, Hirosaki \\ University, Hirosaki. Director: Prof. Ts. Arakawa
}

(Received for publication, August 23, 1956)

The signs of riboflavine deficiency, such as angular stomatitis, cheilosis and swelling of the lingual papillae, were frequently found among children in Hirosaki Area, and these ariboflavinotic signs have been accepted as part manifestations of nutritional dystrophy ${ }^{1}$. In the preceding paper ${ }^{2}$, Kagaya, one of us, reported that the blood level of riboflavine was, in general, lower in children with nutritional dystrophy than in those without it.

In the present investigation riboflavine concentration in the liver specimens biopsied from children with or without nutritional dystrophy will be dealt with.

\section{EXPERIMENTAL}

\section{Method and Material}

The liver biopsy was carried out in the same way as described in Sato's report ${ }^{3}$. Adhering blood was blotted from the biopsied specimens, and 5-10 mg. of them were used for the estimation of riboflavine. The extraction of riboflavine from the liver tissues was performed according to Yagi's procedure ${ }^{4}$ and riboflavine was determined by lumiflavin-fluorometric method ${ }^{5,6)}$.

The histological preparations of the biopsied liver and the description of their microscopic findings were done in the same way as described in Sato's report ${ }^{11}$.

The children subjected to this investigation were the patients admitted into our Clinic. 20 of these children had shown clinical signs of riboflavine deficiency. The rest, 10 in number, had been free from such symptoms. 


\section{Results and Comment}

In the biopsied liver specimens from the 20 cases with nutritional dystrophy, the average for the total riboflavine concentration was $20.8 \pm$ $2.4 \gamma$ per gram, and that for the esterified form was $12.8 \pm 1.5 \gamma$ per gram, corresponding to $61.5 \%$ of the total riboflavine. In the biopsied liver specimens of the 10 children without nutritional dystrophy, the average for the total riboflavine was $28.2 \pm 7.1 \gamma$ per gram, and that for the esterified form was $16.6 \pm 3.2 \gamma$ per gram, being $58.9 \%$ of the total riboflavine ( $\mathrm{Cf}$. Table I and Fig. 1).

On the microscopic examination, the plant cell-like appearance of

$$
\text { TABLE I }
$$

Riboflavine Concentration in the Biopsied Liver Specimens of Children with or without Ariboflavinotic Signs

\begin{tabular}{|c|c|c|c|c|c|c|}
\hline \multirow[b]{2}{*}{ 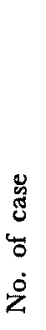 } & \multirow[b]{2}{*}{$\begin{array}{l}\text { Name } \\
\text { and } \\
\text { sex }\end{array}$} & \multirow{2}{*}{ 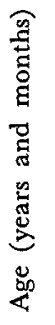 } & \multirow[b]{2}{*}{$\begin{array}{l}\text { Method for nutrition } \\
\text { in infancy }\end{array}$} & $\begin{array}{l}\text { Signs of } \\
\text { rivoflavine } \\
\text { deficiency }\end{array}$ & \multirow{2}{*}{ 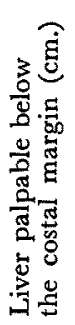 } & \multirow[b]{2}{*}{ Clinical diagnosis } \\
\hline & & & & 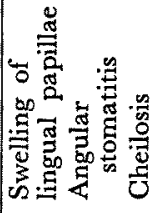 & & \\
\hline 1 & O.K. 우 & 4.0 & Mother's milk & $H--$ & 4.5 & $\begin{array}{l}\text { Nutritional dystro- } \\
\text { phy }\end{array}$ \\
\hline 2 & T.M. 우 & 3.1 & Dried milk & $H-+$ & 0.5 & Mongolian idiocy \\
\hline 3 & A.T. $\hat{\sigma}$ & 1.1 & Dried milk + rice flour & H -+ & 3.0 & Rickets \\
\hline 4 & K.R. 우 & 0.6 & Rice flour +dried milk & $H--$ & 3.0 & $\begin{array}{l}\text { Nutritional dystro- } \\
\text { phy }\end{array}$ \\
\hline 5 & N.Y. & 0.2 & Mother's milk+rice flour & $H--$ & 4.5 & $\begin{array}{l}\text { Enlargement of the } \\
\text { liver }\end{array}$ \\
\hline 6 & N.N. 우 & 5.2 & $\begin{array}{l}\text { Mother's milk }+ \\
\text { cow's milk }\end{array}$ & ++- & 0.5 & $\begin{array}{l}\text { Nutritional dystro- } \\
\text { phy }\end{array}$ \\
\hline 7 & H.S. 우 & 0.6 & Dried milk & $-\quad-\quad-$ & 0.5 & Rhinopharyngitis \\
\hline 8 & H.K. $\widehat{\delta}$ & 5.1 & Mother's milk + rice flour & $H+-$ & 1.5 & Mongolian idiocy \\
\hline 9 & N.K. $\delta$ & 0.9 & Mother's milk & $-\quad-$ & 0.5 & $\begin{array}{l}\text { Tuberculosis of } \\
\text { hiliar limph nodes }\end{array}$ \\
\hline 10 & S.Y. $\delta$ & 1.8 & Dried milk & $-\quad-$ & 1.5 & $\begin{array}{l}\text { Diaphragmatic } \\
\text { hernia }\end{array}$ \\
\hline 11 & I.M. $\delta$ & 2.1 & Dried milk & $-\quad-$ & 1.5 & Rickets \\
\hline
\end{tabular}




\begin{tabular}{|c|c|c|c|c|c|c|c|c|}
\hline 12 & M.F. $\quad$ 우 & 4.0 & $\begin{array}{l}\text { Mother's milk+ } \\
\text { dried milk }\end{array}$ & 世 & - & - & 7.0 & Pick's polyserositis \\
\hline 13 & Y.S. 令 & 5.2 & $\begin{array}{l}\text { Mother's milk }+ \\
\text { dried milk }\end{array}$ & H & $H$ & - & 3.0 & Mongolian idiocy \\
\hline 14 & N.K. 9 & 5.1 & Mother's milk & + & H & $H$ & 1.5 & Tuberculosis \\
\hline 15 & N.T. $\delta$ & 2.0 & $\begin{array}{l}\text { Mother's milk }+ \\
\text { dried milk }\end{array}$ & & + & $H$ & 2.0 & $\begin{array}{l}\text { Nutritionol dystro- } \\
\text { phy }\end{array}$ \\
\hline 16 & S.K. $\hat{\delta}$ & 3.9 & Mother's milk & - & - & - & 5.0 & $\begin{array}{l}\text { Enlargement of the } \\
\text { liver }\end{array}$ \\
\hline 17 & M.T. $\delta$ & 6.1 & Mother's milk & $H$ & - & - & 3.5 & $\begin{array}{l}\text { Nutritional dystro- } \\
\text { phy }\end{array}$ \\
\hline 18 & M.S. $\delta$ & 2.6 & Mother's milk & + & - & + & 2.0 & $\begin{array}{l}\text { Tuberculous menin- } \\
\text { gitis + Nutritional } \\
\text { dystrophy }\end{array}$ \\
\hline 19 & K.Y. 우 & 4.9 & Mother's milk & \# & - & - & 3.0 & Mongolian idiocy \\
\hline 20 & M.K. 우 & 0.6 & Mother's milk & - & - & - & 3.0 & Rhinopharyngitis \\
\hline 21 & K.Y. 우 & 1.0 & Mother's milk + rice flour & H & - & + & 3.0 & Atrophy \\
\hline 22 & K.Y. 우 & 1.1 & $\begin{array}{l}\text { Mother's milk }+ \\
\text { dried milk }\end{array}$ & 世 & - & - & 6.0 & Atrophy \\
\hline 23 & K.Y. 우 & 1.2 & Dried milk & $H$ & - & - & 4.0 & Atrophy \\
\hline 24 & K.T. $\quad$ ㅇ & 0.4 & Dried milk + rice flour & $H$ & + & + & 3.0 & Miliary tuberculosis \\
\hline 25 & K.T. 우 & 0.5 & Dried milk & - & - & - & 4.0 & Miliary tuberculosis \\
\hline 26 & K.T. 우 & 0.8 & Dried milk & - & - & - & 3.0 & Miliary tuberculosis \\
\hline 27 & K.H. & 0.7 & Dried milk + rice flour & - & - & - & 2.0 & Atrophy \\
\hline 28 & K.H. $\delta$ & 0.8 & Dried milk & - & - & - & 3.0 & Atrophy \\
\hline 29 & S.I. & 1.4 & Dried milk + rice flour & H & - & + & 3.0 & $\begin{array}{l}\text { Nutritional dystro- } \\
\text { phy }\end{array}$ \\
\hline 30 & S.I. $\delta$ & 1.4 & Dried milk + rice flour & & - & + & 1.0 & $\begin{array}{l}\text { Nutritional dystro- } \\
\text { phy }\end{array}$ \\
\hline
\end{tabular}

the hepatic cells ${ }^{3}$ was found in 13 cases (Cases $1-4,6,8,11,13,17,19$, 21, 26 and 27), and in these cases, the average for the total riboflavine concentration was $18.9 \pm 3.3 \gamma$ per gram and that for the esterified form was $11.7 \pm 2.3 \gamma$ per gram, being $61.9 \%$ of the total riboflavine. The plant cell-like appearance of the hepatic cells was not found in 12 cases (Cases 5, 7, 9, 10, 15, 16, 22, 24, 25, 28, 29 and 30), and in these cases, the average for the total riboflavine was $27.0 \pm \gamma 6.1 \gamma$ per gram and that for the esterified form was $16.7 \pm 2.5 \gamma$ per gram, being $61.9 \%$ of the total 
TABLE IB

Riboflavine Concentration in the Biopsied Liver Specimens of Children with or without Ariboflavinotic Signs

\begin{tabular}{|c|c|c|c|c|c|c|c|}
\hline \multirow{3}{*}{ 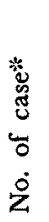 } & \multicolumn{4}{|c|}{ Histological changes of liver } & \multirow{2}{*}{\multicolumn{3}{|c|}{$\begin{array}{l}\text { Riboflavine concentration } \\
\text { in the liver }\end{array}$}} \\
\hline & \multicolumn{3}{|c|}{ Hepetic cells } & \multirow[b]{2}{*}{$\begin{array}{l}\text { Portal } \\
\text { fibrosis }\end{array}$} & & & \\
\hline & $\begin{array}{c}\text { Plant } \\
\text { cell-like } \\
\text { appearance }\end{array}$ & $\begin{array}{l}\text { Fatty } \\
\text { infiltra- } \\
\text { tion }\end{array}$ & Atrophy & & $\begin{array}{l}\text { Total } \\
(r / g)\end{array}$ & $\begin{array}{l}\text { Esterified } \\
(\gamma / g)\end{array}$ & $\begin{array}{l}\text { Ratio of esteri- } \\
\text { fied to total } \\
\text { riboflavine }(\%)\end{array}$ \\
\hline 1 & $H$ & - & - & - & 12.9 & 12.5 & 96.9 \\
\hline 2 & + & - & - & - & 20.0 & 8.3 & 41.5 \\
\hline 3 & + & + & - & + & 13.6 & 9.8 & 72.0 \\
\hline 4 & + & - & - & $H$ & 21.0 & 10.9 & 51.9 \\
\hline 5 & - & - & - & $H$ & 15.5 & 14.0 & 90.3 \\
\hline 6 & $H$ & $H$ & + & - & 21.2 & 15.7 & 74.1 \\
\hline 7 & - & - & - & - & 18.9 & 17.7 & 93.7 \\
\hline 8 & + & - & - & - & 18.9 & 14.8 & 78.3 \\
\hline 9 & - & - & - & - & 30.0 & 26.6 & 88.7 \\
\hline 10 & - & - & - & - & 28.1 & 18.8 & 66.9 \\
\hline 11 & H & - & - & - & 20.1 & 10.8 & 53.7 \\
\hline 12 & & & & & 21.1 & 12.8 & 60.7 \\
\hline 13 & + & & & + & 19.1 & 15.2 & 79.6 \\
\hline 14 & & & & & 32.3 & 15.6 & 48.3 \\
\hline 15 & - & - & $H$ & - & 24.3 & 12.0 & 49.4 \\
\hline 16 & - & - & $H$ & $H$ & 22.4 & 14.5 & 64.7 \\
\hline 17 & + & - & - & - & 12.4 & 8.1 & 65.3 \\
\hline 18 & & & & & 23.2 & 11.0 & 47.4 \\
\hline 19 & H & & & & 18.1 & 16.2 & 89.4 \\
\hline 20 & & & & & 28.2 & 16.0 & 56.7 \\
\hline 21 & $H$ & - & - & - & 15.6 & 3.8 & 24.4 \\
\hline 22 & - & - & - & - & 27.3 & 14.4 & 52.7 \\
\hline 23 & & & & & 22.5 & 13.0 & 57.8 \\
\hline 24 & - & - & - & - & 24.5 & 15.9 & 64.9 \\
\hline 25 & - & - & - & - & 27.1 & 20.0 & 73.8 \\
\hline 26 & + & - & - & + & 33.0 & 11.2 & 33.9 \\
\hline 27 & $H$ & - & - & - & 20.3 & 15.1 & 74.3 \\
\hline 28 & - & - & - & - & 53.6 & 15.2 & 28.4 \\
\hline 29 & - & - & - & - & 30.9 & 15.9 & 51.5 \\
\hline 30 & - & - & - & - & 22.2 & 15.9 & 71.6 \\
\hline
\end{tabular}

* No. of case was the same as in Table I A.

riboflavine (Cf. Table I and Fig. 2). These results showed that the concentration of the riboflavine, in both total and esterified forms, tended to 


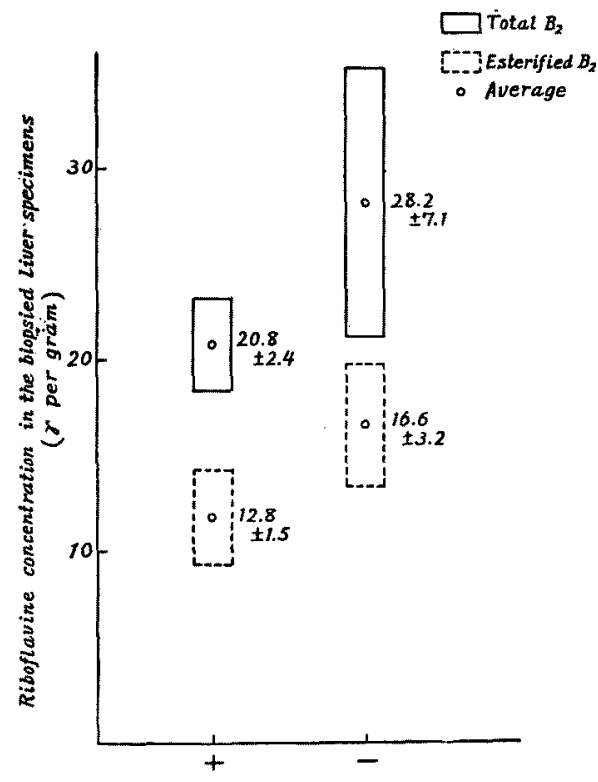

Fig. 1. Riboflavine concentration in the biopsied liver speciments of children with or without ariboflavinotic signs.

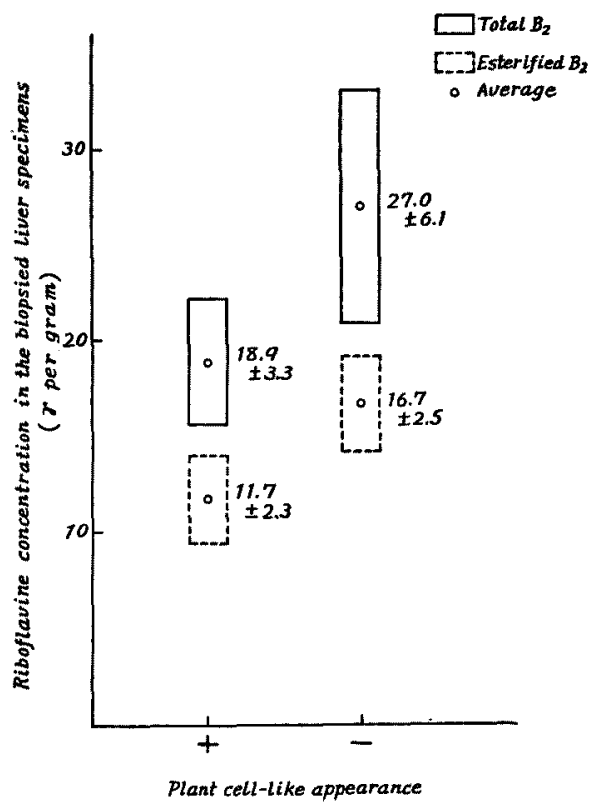

Fig. 2. Riboflavine concentration in the biopsied liver specimens with or without plant cell-like appearance. 
be higher in the biopsied livers without the plant cell-like appearance of the hepatic cells than in those with it (Cf. Fig. 1 and 2).

Sato $^{3)}$ reported from the study of his own materials of liver biopsy that the plant cell-like appearance of the hepatic cells was observed in 22 cases out of 30 cases of the children with nutritional dystrophy and that this histopathological change might be due to high-carbohydrate-lowprotein diet. As reported by Masuda et al. ${ }^{71}$, in most of the inhabitants in this Area, about $60 \%$ of the caloric intake was provided with highly polished rice; vegetable and fish were scanty in variety, and eggs, milk and meat were scarcely taken. In a word, that is "a low protein-high-carbohydrate and B vitamin deficient diet."

Respecting the relationship between riboflavine metabolism and protein depletion, Sarett et al. ${ }^{8)}$ reported that concentration of riboflavine in the liver varied directly with the level of protein in the diet and was independent of the vitamin intake. This finding was later confirmed by Unna et al. ${ }^{9}$, who showed that, in spite of the ingestion of liberal amount of riboflavine, the livers of rats maintained on a low protein diet were unable to retain riboflavine.

The clear relationship between a decreased concentration of riboflavine in the biopsied liver specimens and poor protein intake was observed from Table II, in which only the infants under 12 months were abstracted from the data of the present investigation. In Table II, the cases with ariboflavinotic signs were found in 5 (Cases 4, 5, 21, 24 and 27), all of which were those fed mainly on rice gruel with an addition of small amount of milk preparation or with poorly secreted human milk, and in 3 cases of which plant cell-like appearance of the hepatic cells was observed in the biopsied liver specimens. The concentration of riboflavine in the liver specimens, in both the total and esterified forms, tended to be lower in the infants fed mainly on rice gruel than in those fed on mother's milk or milk preparations exclusively.

\section{Summary and Conclusions}

The riboflavine concentration in the biopsied liver was lower in children with ariboflavinotic signs (as part manifestations of nutritional dystrophy) than in those without same.

Protein deficiency might be one of factors contributing to the development of ariboflavinosis in children in this District, because the riboflavine concentration in the biopsied liver specimens tended to be lower in those cases in which the plant cell-like appearance of hepatic cells was histologically demonstrated than in those without such histological changes. 
TABLE II

Relation among Ariboflavinotic Signs, Riboflavine Concentrationin the Biopsied Liver Specimens and Methods for Nutrition in Infants under 12 months

\begin{tabular}{|c|c|c|c|c|c|c|c|c|c|}
\hline $\begin{array}{l}\text { Method } \\
\text { for } \\
\text { nutri- } \\
\text { tion }\end{array}$ & \multicolumn{3}{|c|}{ Mother's milk } & \multicolumn{3}{|c|}{ Milk preparation } & \multicolumn{3}{|c|}{$\begin{array}{l}\text { Mainly rice gruel with } \\
\text { an addition of small } \\
\text { amount of mother's milk } \\
\text { or milk preparation }\end{array}$} \\
\hline \multirow{2}{*}{$\begin{array}{l}\text { Concent- } \\
\text { ration } \\
\text { of } B_{2} \text { in } \\
\text { liver }\end{array}$} & \multirow{2}{*}{$\begin{array}{l}\text { No. of } \\
\text { case }\end{array}$} & \multicolumn{2}{|c|}{$\mathrm{B}_{2}$ in liver } & \multirow{2}{*}{$\begin{array}{l}\text { No. of } \\
\text { case }\end{array}$} & \multicolumn{2}{|c|}{$\mathrm{B}_{2} \underset{(\tau / g)}{\text { in liver }}$} & \multirow{2}{*}{$\begin{array}{l}\text { No. of } \\
\text { case }\end{array}$} & \multicolumn{2}{|c|}{$B_{2}$ in liver } \\
\hline & & Total & $\begin{array}{l}\text { Esteri- } \\
\text { fied }\end{array}$ & & Totol & $\begin{array}{l}\text { Esteri- } \\
\text { fied }\end{array}$ & & Total & $\begin{array}{l}\text { Esteri- } \\
\text { fied }\end{array}$ \\
\hline & 9 & 30.8 & 26.6 & 7 & 18.9 & 17.7 & $(4) *$ & 21.0 & 10.9 \\
\hline & 10 & 28.2 & 16.6 & 25 & 27.1 & 20.0 & (5) & 15.5 & 14.0 \\
\hline & & & & $26 *$ & 33.0 & 11.2 & $(21)^{* *}$ & 15.6 & 3.8 \\
\hline & & & & 28 & 53.6 & 15.2 & (24) & 24.5 & 15.9 \\
\hline & & & & & & & $(27) \div$ & 20.3 & 15.1 \\
\hline & Average & $\begin{array}{l}29 \cdot 1 \\
\pm \\
14.9\end{array}$ & $\begin{array}{c}21.3 \\
\pm \\
95.1\end{array}$ & Average & $\begin{array}{c}33.1 \\
\pm \\
23.6\end{array}$ & $\begin{array}{c}16.0 \\
\pm \\
6.1\end{array}$ & Average & $\begin{array}{c}19.4 \\
\pm \\
4.6\end{array}$ & $\begin{array}{c}11.9 \\
H \\
6.2\end{array}$ \\
\hline
\end{tabular}

* The cases in which plant cell-like appearance of the hepatic cells was demonstrated by liver biopsy. ( ) The cases with ariboflavinotic signs.

\section{References}

1) Arakawa, Wada, \& Takahashi, Tohoku J. Exp. Med., 1951, 55, 16.

2) Kagaya, Vitamins (Jap.), 1954, 7, 563.

3) Sato, Tohoku J. Exp. Med., 1955, 63, 93.

4) Yagi, Recent Methods for Vitamin Assay (Japan.), 1st ed., Ishiyaku Schuppan., Tokyo, 1954.

5) Kagaya, Vitamins (Jap.), 1953, 6, 777.

6) Fujita, Vitamins (Jap.), 1950, 3, 146.

7) Masuda, Okumura, Aoyama, \& Obara, J. Vitaminology, 1955, 1, 229.

8) Sarett, \& Perzweig, J. Nutr., 1943, 25, 173.

9) Unna, Singer, Kensler ,Taylors, \& Rhoads, Proc. Soc. Biol. Med., 1944, 55, 254. 